Bartłomiej Bajan

Wawrzyniec Czubak

\title{
Korzyści płynące z integracji poziomej w polskim rolnictwie na przykładzie grup producentów rolnych
}

\begin{abstract}
Streszczenie: Celem opracowania jest wskazanie korzyści wynikających z przynależności do grup producenckich w nawiązaniu do cen uzyskiwanych za swoje produkty przez kooperujących rolników, a co za tym idzie, również ocena słuszności wspierania przez politykę rolną działań służących poprawie integracji poziomej w rolnictwie. Dokonano porównania cen poszczególnych produktów rolnych, uzyskiwanych przez członków grup producenckich ze średnimi cenami skupu w kraju (notowane przez Główny Urząd Statystyczny). Wskazano także na różnice $\mathrm{w}$ przychodach pomiędzy poszczególnymi podmiotami, wynikające z porównania sytuacji alternatywnych. Z przeprowadzonej analizy wynika, że we wszystkich badanych branżach (nasiona roślin oleistych, ziemniaki, ziarna zbóż, mleko) ceny uzyskiwane przez kooperujących rolników były wyższe niż średnie krajowe ceny skupu. Ponadto, przy założeniu identycznych wolumenów sprzedaży jak w grupach producenckich, uzyskiwali oni znaczące przewagi w przychodach nad pozostałymi uczestnikami rynku. Świadczy to o relatywnie wyższej sile rynkowej zrzeszających się gospodarstw. Z tego punktu widzenia wsparcie publiczne kierowane na poprawę integracji poziomej znajduje swoje uzasadnienie.
\end{abstract}

Słowa kluczowe: integracja pozioma, grupy producentów rolnych, ceny, przychody.

\section{Wprowadzenie}

Na przestrzeni lat udział rolnictwa w produkcji globalnej malał na rzecz pozostałych sektorów (usług i przemysłu), co widoczne jest szczególnie na przykładzie krajów rozwiniętych, gdzie na początku XXI w. wynosi on nie więcej niż kilka procent. Szybkie zmiany w gospodarce światowej nadal deprecjonują znaczenie gospodarcze gospodarstw rolnych, a w szczególności gospodarstw o małym areale,

Mgr Bartłomiej Bajan, Katedra Ekonomii i Polityki Gospodarczej w Agrobiznesie, Uniwersytet Przyrodniczy w Poznaniu, ul. Wojska Polskiego 28, 60-637 Poznań, bartlomiej.bajan@up.poznan.pl; dr hab. Wawrzyniec Czubak, Katedra Ekonomii i Polityki Gospodarczej w Agrobiznesie, Uniwersytet Przyrodniczy w Poznaniu, ul. Wojska Polskiego 28, 60-637 Poznań, czubak@up.poznan.pl. 
powodując zmniejszenie się ich siły rynkowej ${ }^{1} \mathrm{w}$ samym sektorze. W związku z tym rządy wielu wysokorozwiniętych państw (zwłaszcza Unii Europejskiej) podjęły działania zachęcające rolników do kooperacji w ramach procesu integracji poziomej. Sam proces należy rozumieć jako łączenie się ze sobą podmiotów gospodarczych należących do tej samej fazy produkcji lub dystrybucji. Jednak integrować można także wyodrębnione czynności, co pozwala na zachowanie podmiotowości poszczególnym członkom procesu. W praktyce integracja pozioma odbywa się na zasadzie współpracy kilku podmiotów w obrębie wybranego sektora, branży czy działania, co zmniejsza ich koszty oraz zwiększa siłę rynkową. Przekłada się to na lepszą pozycję negocjacyjną z dostawcami surowców i odbiorcami produktów i usług, a także pozwala na osiągnięcie efektu skali i synergii. W rolnictwie przejawem integracji na poziomie mikroekonomicznym może być wzajemne użyczanie sobie maszyn i narzędzi, jednak sformalizowanie procesu zapewnia powstawanie grup producenckich. Tworzy je kilka podmiotów, które współpracują ze sobą w zakresie produkcji, dystrybucji czy negocjacji cen.

Celem opracowania jest wskazanie korzyści wynikających z przynależności do grup producenckich $\mathrm{w}$ nawiązaniu do cen uzyskiwanych za swoje produkty przez kooperujących rolników. W przeprowadzonym badaniu dokonano próby weryfikacji tezy o poprawie siły rynkowej podmiotów uczestniczących w procesach integracji poziomej, a co za tym idzie, oceniona została również słuszność wspierania przez politykę rolną działań służących poprawie integracji poziomej w rolnictwie. Autorzy uznają w tym przypadku za słuszne wsparcie, które niesie za sobą realny efekt ekonomiczny, a nie jest jedynie wsparciem o charakterze socjalnym.

Przeprowadzona została analiza cen uzyskiwanych przez wybrane grupy producentów rolnych, które następnie zostały porównane ze średnimi krajowymi cenami sprzedaży. Podjęta tematyka jest istotna ze względu na dynamiczne zmiany zachodzące w łańcuchach żywnościowych, które w znaczący sposób wpływają na relacje sił i zależności pomiędzy ich poszczególnymi ogniwami. W badaniu analizie poddano jedynie gospodarstwa zrzeszone w grupach, korzystające w sposób ciągły z przeznaczonego dla nich wsparcia ze środków pomocowych Unii Europejskiej, co pozwala ocenić w pewnym stopniu zasadność stosowania pomocy publicznej, według wiedzy autorów badania na próbie o takim charakterze nie były dotychczas prowadzone, jednocześnie znajdują one uzasadnienie z powodu bardzo wysokiego odsetka grup producentów rolnych korzystających ze wsparcia.

1 Autorzy używają stwierdzenia „siła rynkowa” w rozumieniu udziału w rynku, pod tym pojęciem kryje się również postrzeganie znaczenia danego podmiotu przez innych uczestników rynku, które jest czynnikiem miękkim. W przekonaniu autorów decydujące znaczenie dla siły rynkowej ma siła przetargowa (negocjacyjna), rozumiana jako zdolność negocjacji cenowej z odbiorcami produktu, jej efektem, w przypadku łańcucha żywności, dla producenta rolnego jest jego udział w cenie detalicznej. 


\section{Powody integracji poziomej w rolnictwie}

Główną przesłanką uzasadniającą konieczność integracji producentów rolnych jest niedoskonałość struktury rynku rolno-spożywczego (Kutkowska, Antosz 2012), której objawem są duże różnice w sile rynkowej podmiotów występujących na poszczególnych etapach łańcucha marketingowego (Chlebicka, Fałkowski, Wołek 2009). Produkcja rolna zbliżona jest do modelu konkurencji doskonałej, w którym występuje bardzo dużo małych podmiotów, a oferowany przez nie produkt jest homogeniczny. Skutkuje to bardzo niską siłą rynkową poszczególnych gospodarstw. Natomiast podmioty zajmujące się wytwarzaniem środków produkcji i dostarczaniem usług dla rolnictwa działają najczęściej w warunkach zbliżonych do struktury oligopolu, który charakteryzuje się wysokimi barierami wejścia i wyjścia z rynku, przez co istnieje na nim niewiele podmiotów, oferujących zróżnicowane produkty. Sytuacja taka umożliwia znacznie większy wpływ na cenę towaru niż w przypadku producentów rolnych. Najwyższą siłę rynkową spośród uczestników rynku rolno-spożywczego mają przetwórcy rolni oraz detaliści. Ich przewaga wynika $\mathrm{z}$ faktu występowania niewielkiej liczby kupujących, co odpowiada strukturze oligopsonu, dzięki czemu mogą oni wpływać na ceny zakupu potrzebnych im towarów (Le Vay 1983; Schrader 1992).

Sytuacja występująca na rynku rolno-spożywczym i w łańcuchu żywnościowym powoduje, że ostateczny udział rolnika w wartości końcowej i cenie finalnej ostatecznego produktu jest stosunkowo niewielki i maleje wraz ze wzrostem stopnia przetworzenia. Taki wniosek płynie z badań Instytutu Ekonomiki Rolnictwa i Gospodarki Żywnościowej dotyczących rozstępów cenowych ${ }^{2}$ w latach 19962008, występujących dla podstawowych produktów żywnościowych (Figiel 2009). Przywołana analiza wskazuje ponadto na duże różnice udziału producenta rolnego w cenie detalicznej w zależności od produktu. W przypadku produktów mięsnych średnio około $30 \%$ ceny detalicznej podstawowych produktów spożywczych miały ceny żywca wieprzowego, wołowego oraz drobiowego. Analogicznie w przypadku produktów zbożowych było to średnio około $20 \%$ ceny detalicznej, a dla produktów mleczarskich około $13 \%$ ceny. Ostatecznie na wszystkich omawianych rynkach (czyli zbóż, mięsa, mleczarskim), udział produkcji rolnej w cenach detalicznych znajdował się w przedziale od 10 do $40 \%$, natomiast udział przetwórcy i detalisty łącznie obejmował od 60 do $90 \%$ ceny detalicznej. Wspólną cechą, dla wszystkich analizowanych w przytoczonym badaniu rozstępów cenowych, jest ich duża zmienność w czasie. Jest to przejaw opóźnienia w transmisji impulsów cenowych, charakterystyczny dla łańcucha marketingowego żywności. Przebieg tego procesu,

2 Rozstęp cenowy należy rozumieć jako różnicę pomiędzy ceną płaconą przez konsumentów (ceną detaliczną) za produkty spożywcze a kwotą otrzymywaną przez producentów surowca rolniczego (Hamulczuk, Stańko 2015). 
a w konsekwencji udział w cenach detalicznych głównych ogniw łańcucha marketingowego, zależy od rozkładu siły rynkowej, a więc również od konkurencyjności podmiotów tej struktury.

Szansą na poprawę współpracy rolników, a co za tym idzie zniwelowanie różnic w strukturze sił rynkowych, jest integracja pozioma producentów rolnych, która w swoich założeniach pozwala na polepszenie pozycji negocjacyjnej w stosunku do pozostałych uczestników rynku (Sobczak, Wielechowski 2013). Szczególne znaczenie ma to $w$ warunkach polskich, gdzie niski stopień organizacji producentów rolnych wciąż pozostaje jednym z ważniejszych problemów rolnictwa (Stoma 2013). Sytuacja ta jest tym bardziej niekorzystna, że potęguje ją słaba struktura agrarna (duże rozdrobnienie gospodarstw), co prowadzi do silnej presji rynkowej na podmioty działające samodzielnie (Wigier 1997). Zespołowa działalność rolników otwiera perspektywy uzyskania korzyści pozwalających na umocnienie pozycji konkurencyjnej gospodarstw rolnych podejmujących współpracę (Boguta 2006). Wynika $z$ tego, że szansę na poprawę sytuacji sektora rolnego w Polsce dają starania mające na celu pogłębianie procesów integracji poziomej, rozumianej jako grupowe działania rolników przynoszące korzyści, niemożliwe do osiągnięcia w pojedynkę (Lemanowicz 2004).

Podstawowym elementem struktury dobrze funkcjonującego rynku rolnego są grupy producenckie, na co wskazują doświadczenia krajów przodujących w rozwoju sektora (Tomczak 2009). Według Piotra Chałupki (1998) grupa producencka to zrzeszenie powoływane w sposób dobrowolny i oddolny w celu prowadzenia wspólnej działalności, najczęściej zbytu produkcji. Należy mieć jednak na uwadze, że w Polsce procesy integracji poziomej blokuje niechęć samych rolników. Powodów negatywnego nastawienia względem zrzeszania się w grupy jest kilka. Należy upatrywać ich szczególnie w złych doświadczeniach z lat 80 . XX w. oraz niechęci producentów rolnych do podejmowania długoterminowych zobowiązań. Inną przyczyną jest mentalność rolników, ich silny indywidualizm i brak wzajemnego zaufania oraz niechęć do zmian (Kutkowska, Antosz 2012), a także obawy przed nieetycznym postępowaniem potencjalnych partnerów (Hasiński 2013; Kotala 2003; Wiatrak 2006). W literaturze przedmiotu niechęć do współpracy znajduje odzwierciedlenie w poglądach Friedricha Augusta von Hayeka (2004), który uważa, że kooperacja wymaga wypracowania kompromisu odnośnie do celów oraz metod ich osiągania. W związku z tym ma ona sens jedynie pomiędzy niewielką ilością podmiotów, które jednocześnie powinny charakteryzować się zbliżonym sposobem działania oraz hołdować jednakowym zasadom i mieć podobne przekonania. Zdaniem Hayeka współdziałanie jest pozbawione sensu w momencie, gdy trzeba dostosowywać się do nieznanych warunków. W kontekście rolnictwa owe nieznane warunki są związane z wysoką zmiennością cen na rynku. Dodatkowo przy dynamicznie zmieniającym 
się otoczeniu pojedyncze podmioty wykazują zdolność do szybszego reagowania niż ma to miejsce w grupie, gdzie proces podejmowania decyzji jest obarczony koniecznością negocjacji pomiędzy jej członkami. Niezależnie od wątpliwości teoretycznych związanych z kooperacją przez organizowanie się w grupy producenckie, można wyróżnić wiele korzyści wynikających z uczestnictwa w procesie ich tworzenia. Do najważniejszych zalicza się: ograniczenie liczby pośredników, lepszą pozycję negocjacyjną z dostawcami nawozów, środków ochrony roślin oraz z odbiorcami produktu, co wiąże się z wyższymi jednostkowymi przychodami członków grupy, wspólne inwestycje, wspólne przygotowanie produktów (magazynowanie, suszenie, konfekcjonowanie, pakowanie i oznakowanie), wspólna promocja produktu, wymiana doświadczeń technologicznych oraz informacji rynkowej czy rozłożenie ryzyka na wszystkich członków grupy (Promocja tworzenia... 2011).

\section{Ceny sprzedaży jako wyznacznik siły rynkowej}

To, czy korzyści wynikające z uczestnictwa w grupie producenckiej przewyższają koszty, a więc czy dochodzi do poprawy siły rynkowej, ma znaczenie nie tylko dla samego rolnika, ale także dla organów państwa. Wielowymiarowe korzyści integracji (np. rozwiązanie problemów produkcyjnych czy dochodowych w rolnictwie, zdolność do implementacji innowacyjności [Domagalska-Grędys 2016]) skłaniają instytucje do wdrażania systemu pomocy publicznej (np. w ramach działań Wspólnej Polityki Rolnej Unii Europejskiej) wspierającego procesy prowadzące do rozwoju integracji poziomej. Jak wynika z Raportu końcowego oceny ex post Programu Rozwoju Obszarów Wiejskich 2004-2006 (Ewaluacja ex post... 2009), z budżetu wypłacono ponad 24 miliony złotych wsparcia dla 79 grup producentów rolnych. W sumie z tytułu PROW 2004-2006 wydano decyzje o łącznym wsparciu grup na kwotę ponad 41 milionów złotych, jednak pozostała część tych środków została wypłacona z budżetu PROW 2007-2013. Według danych Agencji Restrukturyzacji i Modernizacji Rolnictwa z 31 grudnia 2015 r. na pomoc zrzeszającym się gospodarstwom w budżecie PROW 2007-2013 przeznaczono ponad 750 milionów złotych.

W celu weryfikacji tezy o poprawie siły rynkowej zrzeszających się gospodarstw przeprowadzona została analiza cen uzyskiwanych przez wybrane grupy producentów rolnych, które przez okres 5 kolejnych lat otrzymywały środki z PROW 2007-2013. W badaniach wykorzystano sprawozdania oraz niepublikowane dane Agencji Restrukturyzacji i Modernizacji Rolnictwa z realizacji działania 142 „grupy producentów rolnych". Ceny zostały obliczone na podstawie wolumenu i wartości netto sprzedaży poszczególnych produktów, a następnie porównane ze średnimi krajowymi cenami sprzedaży, notowanymi i podawanymi przez Główny Urząd 
Statystyczny (dane publikowane w Rocznikach Statystycznych Rolnictwa). Dane, na podstawie których obliczono ceny uzyskiwane przez grupy producentów rolnych, sporządzono dla kolejnych lat działalności (rok liczony jest od momentu założenia grupy), z kolei dane GUS podane są w ujęciu rocznym (od 1 stycznia do 31 grudnia). Dla zwiększenia porównywalności przyjęto, że ceny uzyskiwane $\mathrm{w}$ grupach zajmujących się produkcją roślinną $\mathrm{w}$ danym roku są liczone dla zrzeszeń powstałych od początku czwartego kwartału poprzedniego roku³ Natomiast $\mathrm{w}$ produkcji zwierzęcej ceny $\mathrm{w}$ danym roku obliczono dla grup powstałych od 16 lipca roku poprzedniego. Podział ten ustalono na podstawie uwarunkowań obu rodzajów działalności, w szczególności uwzględniając skoncentrowane $\mathrm{w}$ czasie roku zbiory w przypadku upraw, a także całoroczny charakter produkcji zwierzęcej. Badanie przeprowadzono dla 59 grup producentów rolnych, a więc wszystkich spełniających przyjęte kryteria, z czego wyodrębniono cztery branże, tj.: nasiona roślin oleistych, ziemniaki, ziarno zbóż, mleko. W przeprowadzonej analizie posłużono się metodą opisową oraz metodą porównawczą. Ponadto użyte zostały elementy statystyki opisowej, takie jak wskaźnik struktury i dynamiki. Zastosowano również współczynnik średniorocznego tempa zmian $\left(r_{g}\right)$, według wzoru: $r_{g}=\frac{-3 m\left[9 m^{2}+24 m(n-1)\left(\frac{1}{y_{1}} \sum_{t=1}^{n} y_{t}-n\right)\right]^{1 / 2}}{2 m(n-1)} 100 \%$ (Wysocki, Lira 2005).

W całym badaniu dokonano również porównań przychodów ze sprzedaży uzyskiwanych $\mathrm{w}$ grupach producenckich $\mathrm{z}$ przychodami uzyskiwanymi w pozostałych gospodarstwach krajowych przy założeniu takiego samego wolumenu sprzedaży. Założenie to jest pewnym uproszczeniem sytuacji występującej w rzeczywistości, gdzie sam wolumen sprzedaży jest jednym z czynników kształtujących cenę, jednak czynników tych jest znacznie więcej. W przypadku grup producenckich w szczególności należy pamiętać o wpływie na ceny kontraktów terminowych, gwarancji relatywnie wysokiej jakości produktu czy ogólnych zdolności negocjacyjnych wynikających chociażby z wymiany doświadczeń pomiędzy zrzeszonymi rolnikami.

Pierwszą badaną branżą były grupy producentów nasion roślin oleistych. Analizie poddano 19 grup, czyli około 30\% wszystkich grup w tej branży (według stanu na 31 lipca 2015 r.; za: Czubak, Bajan 2016). Ceny uzyskiwane przez kooperujących rolników zostały porównane ze średnimi cenami rzepaku, po jakich był on sprzedawany przez pozostałe podmioty. $\mathrm{Z}$ analizy danych (rys. 1) wynika,

3 Przykładowo: ceny uzyskiwane przez grupy producentów rolnych w 2008 r. (produkcja roślinna) są liczone na podstawie grup powstałych od 1 października 2007 r. do 30 września 2008 r. (oraz tych powstałych we wcześniejszych latach w przypadku, gdy 2008 nie jest pierwszym rokiem ich działalności). 
że w obu tych przypadkach były one bardzo zbliżone, a średnia różnica w latach 2007-2013 wynosiła niecałe 2 złote za decytonę.

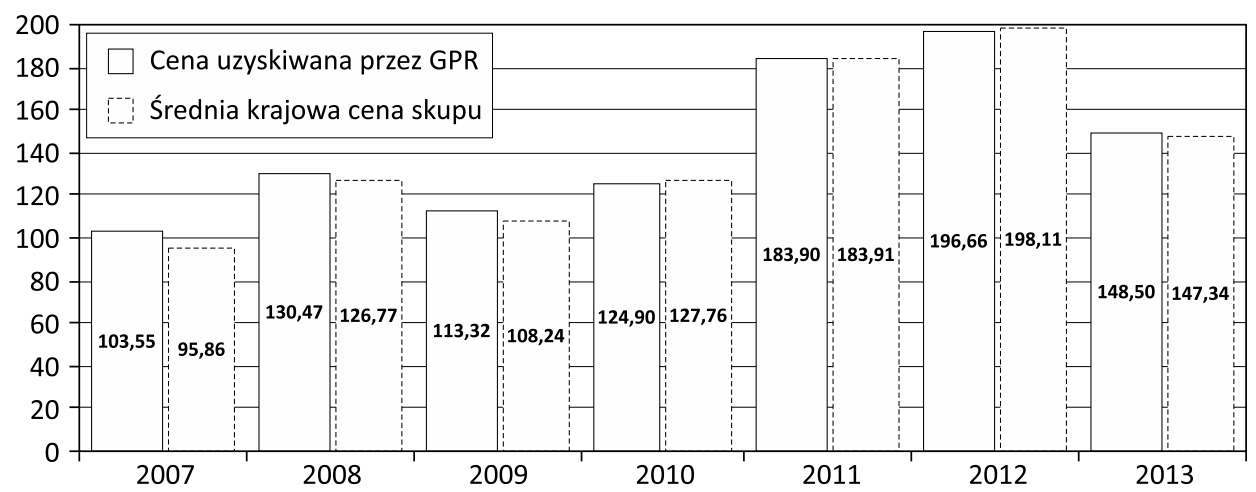

Rysunek 1. Ceny nasion roślin oleistych uzyskiwane przez producentów rolnych w latach 2007-2013 (kwoty w zt/dt)

Figure 1. Oilseed plant seed prices obtained by agricultural producers in the years 2007-2013 (amounts in PLN/dt)

Źródło: opracowanie własne na podstawie danych ARiMR oraz Roczników Statystycznych Rolnictwa GUS. Source: Own study on the basis of ARMA's data and Polish Statistical Yearbooks of Agriculture.

Należy jednak zwrócić uwagę na fakt, że ceny sprzedaży w grupach producentów rolnych kształtują się na wyższym poziomie szczególnie w latach, w których nasiona roślin oleistych są relatywnie tańsze. Może to wskazywać na lepsze zabezpieczenie przed wysokimi spadkami cen. Co istotne, średnioroczne tempo zmian średniej krajowej ceny skupu dla badanego okresu wynosi 9,9\% i jest wyższe od analogicznego dla grup o 1,7 punktu procentowego. Jest to różnica niewielka, z korzyścią dla producentów niezrzeszonych, jednak głównym powodem takiego stanu rzeczy jest znacznie niższa cena początkowa w 2007 r., czyli pierwszym roku analizy.

Niewielka średnia różnica w uzyskiwanej cenie $(1,4 \%)$ nie potwierdza jednoznacznie tezy o przewadze negocjacyjnej grup producentów nasion roślin oleistych w kontaktach z odbiorcami produktu. Należy mieć jednak na uwadze skalę, której to dotyczy, gdyż średnio w badanym okresie każdy producent zrzeszony w grupie sprzedawał ponad 410 ton gotowego produktu, co rocznie daje ponad 8 tys. złotych więcej dodatkowego przychodu ze sprzedaży niż wśród pozostałych podmiotów ${ }^{4}$ (jest to około 1,4\% średniego przychodu przypadającego na jedno gospodarstwo).

4 Analiza przychodów w całym opracowaniu przeprowadzona została przy założeniu takiej samej wielkości sprzedaży jak ta realizowana przez gospodarstwa zrzeszone w grupach producentów rolnych. 
Znacznie większe różnice w cenach sprzedaży zaobserwowano pomiędzy analizowanymi grupami podmiotów w przypadku ziemniaków, gdzie średnia cena za 1 decytonę w grupach producenckich była wyższa o prawie 7 złotych w latach 2007-2013 (rys. 2).

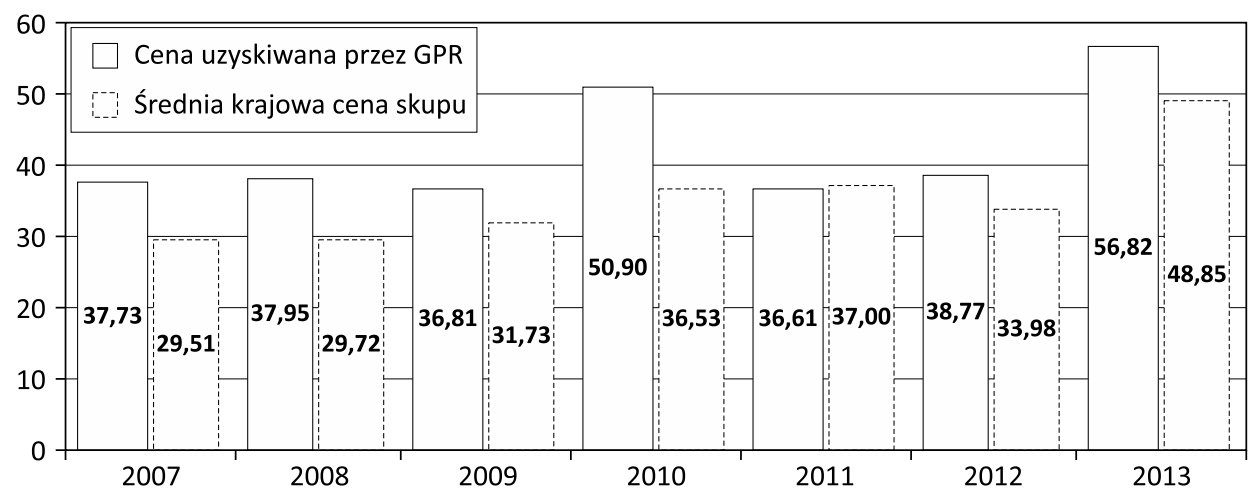

Rysunek 2. Ceny ziemniaków uzyskiwane przez producentów rolnych w latach 20072013 (kwoty w zt/dt)

Figure 2. Potatoes prices obtained by agricultural producers in the years 2007-2013 (amounts in PLN/dt)

Źródło: opracowanie własne na podstawie danych ARiMR oraz Roczników Statystycznych Rolnictwa GUS. Source: Own study on the basis of ARMA's data and Polish Statistical Yearbooks of Agriculture.

Z analizy przeprowadzonej dla blisko $20 \%$ grup w tej branży wynika, że średnia cena sprzedaży w badanym okresie nie spadła poniżej 36 złotych za decytonę. Natomiast wśród pozostałych podmiotów w latach 2007-2008 kształtowała się poniżej 30 złotych. Jednocześnie ceny uzyskiwane przez zrzeszone gospodarstw były bardzo stabilne, o czym świadczy choćby średnioroczne tempo zmian na poziomie $2,8 \%$, podczas gdy ogólnie w kraju wyniosło ono $4,5 \%$. Ponownie więc, jak w przypadku nasion roślin oleistych, średnioroczne tempo zmian było wyższe dla cen krajowych, jednak za przyczyną znacznie niższych cen w początkowych latach badanego okresu. Średnia cena ziemniaków w grupach producenckich była wyższa o ponad $16 \%$ i gdyby porównać ją z potencjalnymi efektami ekonomicznymi sprzedaży po przeciętnych cenach krajowych, to różnica w przychodach w badanym okresie wyniosłaby około 75 tys. złotych rocznie dla średniego wolumenu $\mathrm{z}$ lat 2007-2013 (jest to około 16\% średniego przychodu przypadającego na jedno gospodarstwo). Na przykładzie producentów ziemniaków zrzeszonych w grupach widać, że dysponują oni znacznie wyższą siłą rynkową niż pozostałe podmioty. Bardzo ważne wydaje się nie tylko uzyskiwanie wyższych cen za wytwarzane produkty, ale 
też zabezpieczenie przed spadkiem poniżej pewnego, stabilnego poziomu ( $\mathrm{w}$ tym przypadku 36 złotych za decytonę), co można zaobserwować w całym badanym okresie. Taka sytuacja pozwala lepiej planować procesy właściwe dla gospodarstw rolnych, ponieważ gwarantuje względną stabilizację cen na odpowiednim poziomie.

Kolejną analizowaną grupą towarową były zboża i grupy producentów zbóż. Przyjęte w badaniu kryteria spełniło prawie 25\% łącznej liczby grup producenckich z tej branży. Uzyskiwane przez nie ceny zbytu porównano ze średnią arytmetyczną krajowych cen pszenicy i kukurydzy ${ }^{5}$. Dane o sprzedaży zbóż w grupach producenckich podane są jako agregat (brak jest podziału na rodzaje zbóż), co stwarza problem słabszej ich porównywalności, jednak nadal pozwala weryfikować zasadniczą istotność różnic cen.

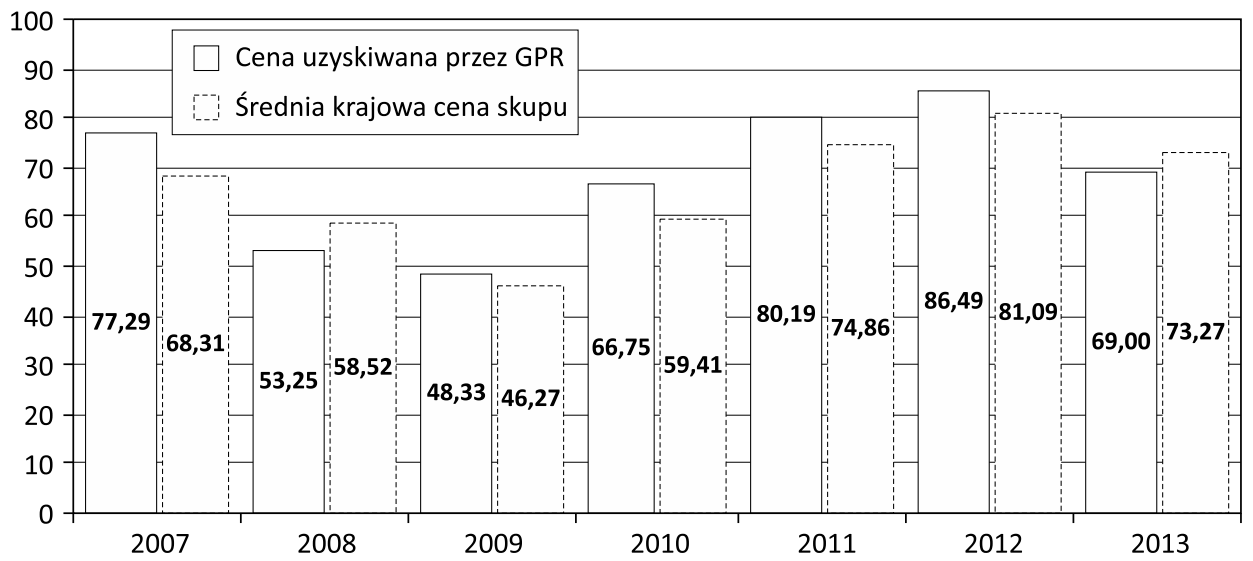

Rysunek 3. Ceny ziarna zbóż uzyskiwane przez producentów rolnych w latach 20072013 (kwoty w zt/dt)

Figure 3. Grain cereal prices obtained by agricultural producers in the years 20072013 (amounts in PLN/dt)

Źródło: opracowanie własne na podstawie danych ARiMR oraz Roczników Statystycznych Rolnictwa GUS. Source: Own study on the basis of ARMA's data and Polish Statistical Yearbooks of Agriculture.

Średnia cena uzyskiwana w grupach producenckich była wyższa o prawie 3 złote na 1 decytonę (rys. 3), jednak średnioroczne tempo zmian przyjmuje wartość ujemną na poziomie $-2,9 \%$, a dla pozostałych podmiotów jedynie $-0,9 \%$. Wartości te wynikają z wysokiej ceny sprzedaży w pierwszym roku analizy - czyli w 2007 r. Szczegółowa analiza wykazała, że przy założeniu występowania średniego

5 W porównaniu przyjęto ceny pszenicy i kukurydzy ze względu na największy udziału tych dwóch zbóż w strukturze sprzedaży. 
wolumenu sprzedaży z lat 2007-2013 przeciętnie jeden zrzeszony producent rolny w tej branży uzyskiwał przychód wyższy o prawie 35 tys. złotych rocznie od pozostałych podmiotów (jest to około 4\% średniego przychodu przypadającego na jedno gospodarstwo). Pomimo wyższych cen dla kooperujących rolników, ceny te podlegały większym fluktuacjom niż w przypadku pozostałych gospodarstw. Nie jest to jednoznaczne w interpretacji, ponieważ rynek zbóż charakteryzuje się bardzo wysoką zmiennością cen ze względu na coroczne wahania w wolumenie produkcji, na który oddziałuje wiele czynników zewnętrznych niezależnych od producentów.

Inaczej kształtuje się sytuacja w przypadku produkcji zwierzęcej, gdzie w szczególności zmiany pogody nie odgrywają aż tak dużej roli w zmienności cen i w związku z tym rolnik ma lepszą kontrolę nad skalą wytwarzania. Wyjątek w tym przypadku stanowią hodowcy krów mlecznych, w przypadku których warunki rynkowe zmieniły działania administracyjne, czyli zniesienie kwot mlecznych w marcu 2015 r. Analiza cen mleka obejmowała 10\% grup z tej branży i została przeprowadzona dla lat 2008-2013, a więc przez cały ten okres obowiązywał system kwotowania. Jest to o tyle istotne, że wiąże się z ograniczoną możliwością rozwoju produkcji i przez to większej siły negocjacyjnej w zakresie cen. Wszelkie różnice w cenie będą zatem mocno uwypuklały przewagi w sile rynkowej poszczególnych podmiotów.

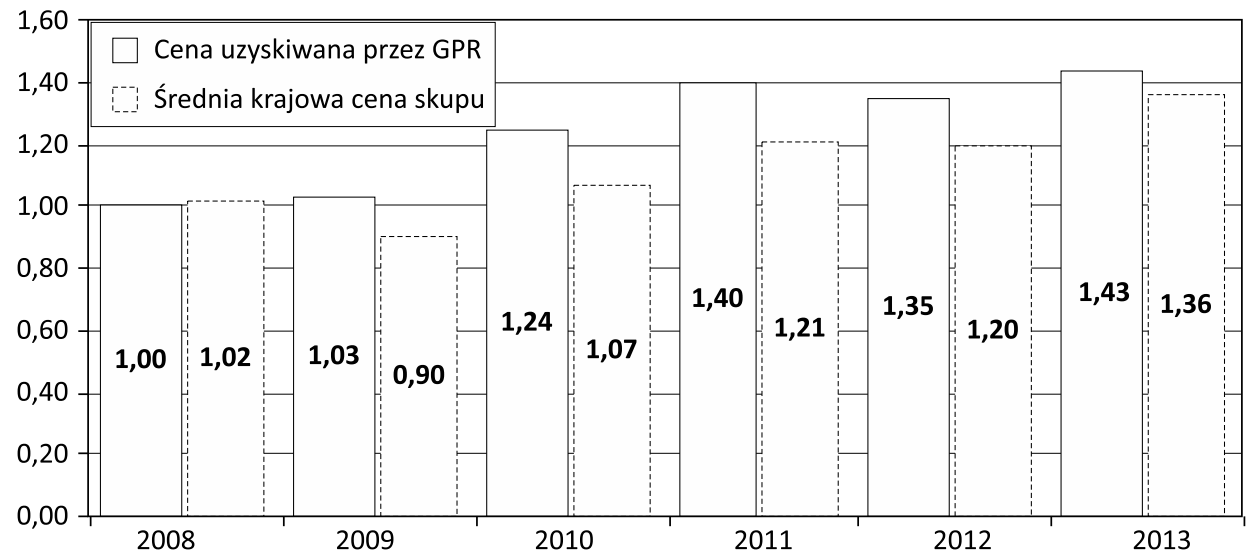

Rysunek 4. Ceny mleka uzyskiwane przez producentów rolnych w latach 2008-2013 (kwoty w zt/l)

Figure 4. Milk prices obtained by agricultural producers in the years 2008-2013 (amounts in PLN/dt)

Źródło: opracowanie własne na podstawie danych ARiMR oraz Roczników Statystycznych Rolnictwa GUS. Source: Own study on the basis of ARMA's data and Polish Statistical Yearbooks of Agriculture. 
Przeprowadzone badania wskazują na uzyskiwanie przez grupy producenckie cen wyższych średnio o 0,12 zł za litr mleka niż u pozostałych podmiotów rynku (rys. 4). Jest to duża różnica, zważywszy na to, że wynosi ponad $10 \%$ średniej ceny uzyskiwanej przez niezrzeszone gospodarstwa. Przy założeniu występowania uśrednionego wolumenu sprzedaży z lat 2008-2013 daje to różnicę w przychodach o wartości powyżej 37 tys. złotych rocznie na korzyść kooperujących rolników (jest to około 9,5\% średniego przychodu przypadającego na jedno gospodarstwo). Dodatkowo średnioroczne tempo zmian dla grup wynosi 6,4\% i jest wyższe o 3,6 punktu procentowego niż to obliczone dla średniej ceny skupu. $\mathrm{Na}$ tym przykładzie widać, że kooperujące podmioty mają znaczącą przewagę w negocjacjach $\mathrm{z}$ odbiorcami produktu.

\section{Podsumowanie}

Z przeprowadzonych analiz wynika, że rolnicy zrzeszeni w grupach producenckich, niezależnie od branży, w której działają, osiągali średnio wyższe ceny za swoje produkty od pozostałych uczestników rynku. Pozwala to stwierdzić, że przy założeniu identycznych wolumenów sprzedaży przychody zrzeszonych rolników były wyższe. Potwierdza to symulacja przeprowadzona na podstawie średniej ilości zbywanych towarów w grupach. Jedynie w przypadku nasion roślin oleistych różnica w uzyskiwanych cenach wydaje się umiarkowana, natomiast w pozostałych badanych branżach jest ona znaczna. Konkludując powyższe rozważania, można dojść do wniosku, że integracja pozioma w polskim rolnictwie sprzyja poprawie siły rynkowej producentów rolnych. Takie stwierdzenie daje również silne podstawy uznania zasadności wspierania tego procesu ze środków publicznych w celu jego przyspieszenia. Należy jednak zaznaczyć, że pełna ocena skuteczności dotychczas stosowanych mechanizmów jest osobnym zagadnieniem. Aby uzyskać dokładny obraz efektywności organizowania się rolników w grupy producenckie, powyższą analizę należałoby poszerzyć o stronę kosztową. Dopiero w takim przypadku można będzie całościowo ocenić pełne korzyści dla grup producentów rolnych.

\section{Bibliografia}

Boguta W. (red.) (2006). Organizacja i funkcjonowanie grup producentów rolnych. Warszawa: Krajowa Rada Spółdzielcza.

Chałupka P. (1998). Ekonomiczne, organizacyjne oraz prawne aspekty organizowania się rolników. Leszno: Wojewódzki Ośrodek Doradztwa Rolniczego.

Chlebicka A., Fałkowski J., Wołek T. (2009). Powstawanie grup producentów rolnych a zmienność cen. Zagadnienia Ekonomiki Rolnej, 2 (319), 59-73. 
Czubak W., Bajan B. (2016). The impact of rdp 2007-2013 on integration of polish agricultural producers based on the action "agricultural producer groups". Journal of Agribusiness and Rural Development, 41 (3), 283-292.

Domagalska-Grędys M. (2016). Kontekst innowacji w grupach producentów rolnych. Wieś i Rolnictwo, 1 (170), 139-164.

Ewaluacja ex post Planu Rozwoju Obszarów Wiejskich 2004-2006. Raport końcowy (2009). Warszawa; https://www.minrol.gov.pl/ [dostęp: 12.12.2017]

Figiel S. (2009). Równowaga wzrostu produkcji w sektorze rolno-spożywczym - rozwój metod analitycznych i ich weryfikacja ex-post i ex-ante. Warszawa: Instytut Ekonomiki Rolnictwa i Gospodarki Żywnościowej.

Hamulczuk M., Stańko S. (2015). Sezonowość i cykliczność cen oraz ich relacji w łańcuchu marketingowym wieprzowiny. Roczniki Naukowe Ekonomii Rolnictwa i Rozwoju Obszarów Wiejskich, 3 (102), 7-19.

Hasiński W. (2013). Grupy producentów rolnych w Polsce ze szczególnym uwzględnieniem Dolnego Śląska. Wrocław: Instytut Geografii i Rozwoju Regionalnego Uniwersytetu Wrocławskiego.

Kotala A. (2003). Rola grup producenckich w zwiększeniu skali produkcji i konkurencyjności gospodarstw rolnych Polski południowej. W: L. Strzelczak (red.). Rozwój agrobiznesu na obszarach wiejskich wobec integracji z Unią Europejska. Kraków: Wydawnictwo Akademii Rolniczej im. Hugona Kołłątaja w Krakowie.

Kutkowska B., Antosz I. (2012). Szanse i zagrożenia rozwoju grup producentów rolnych. Wieś i Rolnictwo, 4 (157), 91-111.

Lemanowicz M. (2004). Grupy producenckie i marketingowe i ich wpływ na pozycje konkurencyjną rolników na rynku. Acta Scientarium Polonorum, Oeconomia, 3, 103-115.

Le Vay C. (1983). Agricultural Co-operative Theory. A Review. Journal of Agricultural Economics, 34 (1), 1-44.

Promocja tworzenia grup producentów rolnych (2011). Warszawa: Ministerstwo Rolnictwa i Rozwoju Wsi.

Schrader L. (1992). Economic justification. W: D.W. Cobia (red.). Cooperative in Agriculture (s. 121-136). Englewood Cliffs: Prentice Hall.

Sobczak W., Wielechowski M. (2013). Rozwój grup i organizacji producentów owoców i warzyw w Polsce w świetle unijnego i krajowego ustawodawstwa. Zeszyty Naukowe SGW: Ekonomika i Organizacja Gospodarki Żywnościowej, 103, 161-171.

Stoma M. (2013). Grupy producentów rolnych - uwarunkowania i funkcjonowanie. Lublin: Wydawnictwo Q\&R Polska.

Tomczak P. (2009). Grupy producentów rolnych jako nowe formy zespołowego działania na polskiej wsi. W: E. Rydz, R. Rudnicki (red.). Procesy przekształceń przestrzeni wiejskiej (s. 201-212) (seria Studia Obszarów Wiejskich, t. 17). Warszawa: Polskie Towarzystwo Geograficzne; Instytut Geografii i Przestrzennego Zagospodarowania im. Stanisława Leszczyckiego PAN.

von Hayek F.A. (2004). Zgubna pycha rozumu. O błędach socjalizmu (tłum. M. i T. Kunińscy). Kraków: Arcana. 
Wigier M. (1997). Organizacje producentów rolnych w Unii Europejskiej. Siedlce: Wojewódzki Ośrodek Doradztwa Rolniczego.

Wiatrak A.P. (2006). Grupy producentów rolnych - istota działania i zarządzania nimi. Rocznik Nauk Rolniczych, Seria G, 2 (13), s. 361-365.

Wysocki F., Lira J. (2005). Statystyka opisowa. Poznań: Wydawnictwo Akademii Rolniczej w Poznaniu.

\title{
The Benefits of Horizontal Integration in Polish Agriculture Exampled by Agricultural Producer Groups
}

\begin{abstract}
The purpose of the study is to identify the benefits of belonging to producer groups in relation to the prices received for their products by cooperating farmers and, consequently, also to assess the appropriateness of agricultural policy which supports improvement of horizontal integration in agriculture. A comparison of prices of individual agricultural products obtained by members of producer groups with average procurement prices from the Central Statistical Office (Statistical Yearbooks of Agriculture), has been made. It also indicated differences in revenue between the various entities resulting from the comparison. The analysis shows that in all examined industries (oilseeds, potatoes, cereal grains, milk), the prices received by the cooperating farmers were higher than the average procurement prices. In addition, assuming identical sales volumes as in producer groups, they had significant revenue advantages over the rest of the market. This demonstrates the relatively higher market power of affiliated holdings, and from this point of view also public support directed at improving horizontal integration is justified.
\end{abstract}

Keywords: horizontal integration, agricultural producer groups, prices, revenues. 